Article

\title{
Stem Photosynthesis of Twig and Its Contribution to New Organ Development in Cutting Seedlings of Salix Matsudana Koidz.
}

\author{
Junxiang Liu ${ }^{1,2}$, Lin Gu ${ }^{1}$, Yongchang Yu ${ }^{1}$, Guansheng $\mathrm{Ju}^{1}$ and Zhenyuan Sun ${ }^{1,2, *}$ \\ 1 Key Laboratory of Tree Breeding and Cultivation of State Forestry Administration, Research Institute of \\ Forestry, Chinese Academy of Forestry; Haidian District, Beijing 100091, China; jxliu@caf.ac.cn (J.L.); \\ gulin1123@163.com (L.G.); yyc6335@163.com (Y.Y.); jugs@caf.ac.cn (G.J.) \\ 2 State Key Laboratory of Tree Genetics and Breeding, Chinese Academy of Forestry; Haidian District, Beijing \\ 100091, China \\ * Correspondence: sunzy@caf.ac.cn; Tel.: +86-10-6288-9626
}

Received: 27 February 2018; Accepted: 5 April 2018; Published: 16 April 2018

check for updates

\begin{abstract}
The objective of this study was to illustrate the photosynthetic characteristics of current twigs of Salix matsudana Koidz., and clarify the effect of stem photosynthesis on the new organ development in cutting seedlings. Excised twigs were taken as the experimental samples. The response of the stem photosynthesis rate to increasing light intensity and the effective photochemical efficiency of the cross section of the twig were determined. Then, twigs were used as cuttings and exposed to 0,20 , and $100 \mu \mathrm{mol} \mathrm{m}^{-2} \mathrm{~s}^{-1}$ light intensities, respectively, to achieve distinctive stem photosynthetic rates. After 14 days of treatment, stem water and non-structural carbohydrate (NSC) content, as well as the biomass and carbon isotopic composition, of new organs in the cutting seedlings under different light treatments were examined. The results showed that the gross photosynthetic rate significantly increased within $400 \mu \mathrm{mol} \mathrm{m}^{-2} \mathrm{~s}^{-1}$ of light intensity, and the maximum rate was approximately $1.27 \mu \mathrm{mol} \mathrm{m}^{-2} \mathrm{~s}^{-1}$. The effective photochemical efficiency of the PSII of the cortex was significantly higher than the inner tissues in the cross section of the twig. When twig cuttings were exposed to different light intensities, stem water and starch content, as well as bud and root biomass, were significantly higher in the cutting seedling subjected to $100 \mu \mathrm{mol} \mathrm{m}{ }^{-2} \mathrm{~s}^{-1}$ than the case treated in darkness; however, the bud $\delta^{13} \mathrm{C}$ trend was the opposite. Stem photosynthesis played a positive role in the maintenance of stem water and starch supply for the cutting seedlings, and ${ }^{13} \mathrm{C}$ depleted assimilates produced by stem photosynthesis contributed to bud biomass, revealing that stem photosynthesis promotes organ development in cutting seedlings of Salix matsudana.
\end{abstract}

Keywords: stem photosynthesis; organ development; cutting seedling; nonstructural carbohydrate; carbon isotope discrimination

\section{Introduction}

Inside the stem of woody plants, there is a considerable amount of $\mathrm{CO}_{2}$ produced by the respiration of living cells. As bark forms a physical barrier for the radial diffusion of $\mathrm{CO}_{2}[1,2]$, extremely high internal $\mathrm{CO}_{2}$ concentrations are commonly observed, where the maximum value is around $26 \%[3,4]$. Trees can re-fix a portion of this high internal $\mathrm{CO}_{2}$ derived from respiration and probably in part also by gaseous xylem efflux via photosynthesis in the stem [5]. In this study, this internal $\mathrm{CO}_{2}$ re-fixation process was named 'stem photosynthesis'. Chlorophyll is abundant in the current-year and one-, two-, and three-year old stems of woody trees [6]. Chloroplasts are mainly located in the living bark and cortical parenchyma of stems [3], and are also present within the living 
cells of xylem [7] and sometimes even in the pith [8-10]. These chlorophyll-containing tissues are able to use transmitted light for photosynthesis [11,12].

Stem photosynthetic rates decrease downward along the stem in mature trees [13], and the variation is driven by differences in light availability, bark type, and corticular chlorophyll content $[14,15]$. In young twigs and branches of crown, stem photosynthesis may compensate for $60-90 \%$ of the potential respiratory carbon loss $[8,11,16]$, and the oxygen evolved during photosynthesis plays a decisive role in avoiding stem internal hypoxia [17]. Furthermore, stem photosynthesis may help in bridging the energy and carbon gap during the period between total defoliation and re-foliation [3]. It has been reported that for the defoliation leaves from plants of Prunus ilicifolia (Nutt. ex Hook. \& Arn.) Walp., Umbellularia californica (Hook. \& Arn.) Nutt., and Arctostaphylos manzanita Parry, light exclusion from the stem caused a significant reduction of the ratio of bud dry weight (DW) to total plant DW when compared to the plant subjected to light exposed treatment [18]. The same trend was found in baobab and the castor bean plant [19], showing that bud DW and ratio of bud DW:total DW were both significantly decreased due to the light exclusion from the stem.

Leaf photosynthesis is a ${ }^{13} \mathrm{C}$ fractionation process. The diffusion of $\mathrm{CO}_{2}$ from the ambient air into the leaf and carboxylation inside the chloroplasts by ribulose-bisphosphate carboxylase (Rubisco) were both favorable for ${ }^{12} \mathrm{C}$ relative to ${ }^{13} \mathrm{C}[20,21]$, leading to the ${ }^{13} \mathrm{C}$ depletion in the fixed carbon. Compared to the leaf, stem photosynthesis re-fixes the internal $\mathrm{CO}_{2}$ mainly attributed to the respiration of plant organic matter [22,23]. Due to the respiratory $\mathrm{CO}_{2}$ depletion relative to internal leaf $\mathrm{CO}_{2}$ [24] and the further discrimination against ${ }^{13} \mathrm{C}$ by carboxylase [20], stem photosynthetic assimilates are much more depleted in ${ }^{13} \mathrm{C}$ when compared to the case of leaf photosynthesis [24]. In comparison with light exclusion from the stem, the bud production was significantly increased and the carbon isotopic composition $\left(\delta^{13} C\right)$ of the buds was significantly decreased when exposed to light treatment $[18,19]$. This implies that if stem photosynthetic assimilates contribute to the formation of new organs, the ${ }^{13} \mathrm{C} /{ }^{12} \mathrm{C}$ ratio would be lower than that subjected to the darkness treatment.

For the cutting culture of many woody plants, leaves are removed for reducing water loss. This causes the new organ development to be solely dependent on the carbohydrate supply of the cuttings. Stem photosynthesis is the only carbon assimilation pathway until leaf development to autotrophy to complete during the stem cutting period. Whether it plays an important role for the organ development in cutting seedlings is still not known. Salix L. has been used as a bioenergy production tree species due to its fast-growing, easy-propagation, and short-rotation characteristics [25]. In particular, Salix specimens are considered as good candidates for a phytoremediation approach due to their high tolerance against metal pollutants and high annual biomass production [26]. In the present study, Salix matsudana was taken as the plant material as it is not only prone to propagate by stem cutting, but also has abundant chlorenchymas in the young twigs. Our main objectives were to investigate the effect of stem photosynthesis on bud and root development, and to clarify whether or not it contributes to the new organ formation in cutting seedlings. We hypothesized that: (1) twigs exposed to light treatment will produce more buds and roots than those in the darkness; and (2) if stem photosynthetic assimilates contribute to new organ biomass, the $\delta^{13} \mathrm{C}$ of new organ organic matter under light treatment would be lower than those treated in darkness.

\section{Materials and Methods}

\subsection{Plant Material}

In May 2013, cuttings were taken from the crown of one ten-year old Salix matsudana plant (female) located in the campus of the Chinese Academy of Forestry, which ensured that all the clones had an identical genotype. The cuttings were $15 \mathrm{~cm}$ in length with a base diameter of $2 \mathrm{~cm}$ and were cultured in the nursery of the Chinese Academy of Forestry. The planting spacing was $2 \mathrm{~m} \times 2 \mathrm{~m}$, and the outermost plants were taken as guard rows. 
In July 2015, 33 robust samples were randomly selected inside the guard rows. At a $1.5 \mathrm{~m}$ height above the soil surface, two current-year old twigs in the south orientation of each plant were cut off from the base position in the morning with a mean diameter of $0.5 \pm 0.1 \mathrm{~cm}$. The top and bottom ends were recut under water to maintain the twig segment length of $45 \mathrm{~cm}$. In total, 66 twigs were taken as the experiment samples.

\subsection{Experimental Design}

Six twigs were randomly selected to measure the response curve of stem photosynthesis to different photosynthetically active radiation $(P A R)$. Another six samples were selected to measure the effective photochemical efficiency ( $\Phi P S I I)$ of the cross section. Each twig was taken as one replication for the above two experiments.

As for the other 54 twigs, all samples were entirely defoliated and the buds present were removed by a knife blade. Among them, six samples were randomly selected to be placed in an opaque plastic box $(33 \mathrm{~cm} \times 15 \mathrm{~cm} \times 12 \mathrm{~cm}$ ) containing $5 \mathrm{~L}$ water, and were then cultured in a climatic chamber with 0,20 , and $100 \mu \mathrm{mol} \mathrm{m}^{-2} \mathrm{~s}^{-1}$ light intensity, respectively, continuously being aerated and replaced with water every three days. Each chamber contained three boxes, and each box was taken as one replication. All the chambers were held at $25^{\circ} \mathrm{C}, 60 \%$ relative humidity, and a $14 \mathrm{~h}$ light $/ 10 \mathrm{~h}$ dark photoperiod. During the experimental period, the treatments $\left(0,20\right.$, and $\left.100 \mu \mathrm{mol} \mathrm{m}^{-2} \mathrm{~s}^{-1}\right)$ were rotated among the three growth chambers every two days to balance the confounding effects, except for light intensity driven from the different chamber. Buds were harvested when they were not yet autotrophic, immediately put in liquid nitrogen, and then stored at $-20{ }^{\circ} \mathrm{C}$ until analysis. In order to guarantee that the stem was the only photosynthetic organ, bud sampling was utilized to prevent them developing into autotrophic organs. Two weeks later, three cutting seedlings were randomly selected from one box. One was divided into bud, root, and stem, with the total bud number, root length, and stem fresh weight (FW) measured, and the ratio of die back area to the whole stem surface was determined. In this study, the stem surface changing into black was taken as the criteria identifying die back. Then, all samples were oven dried at $70{ }^{\circ} \mathrm{C}$ until a constant DW was obtained, and the absolute water content of the stem was determined. Two stem segments were taken from the second seedling, and one was stored at $-80^{\circ} \mathrm{C}$ for photosynthetic pigment analysis, while the other was oven dried for soluble sugar and starch content analysis. The stem bark and present buds were separated from the third seedling together with the buds harvested during the treatment period. They were subsequently oven dried at $70^{\circ} \mathrm{C}$ until the constant DW was achieved, which were then taken as samples for bark and bud carbon stable isotope analysis.

\subsection{Methods}

\subsubsection{Response of Stem Photosynthesis to Light Intensity}

Gas exchange was measured in the laboratory on detached twigs with an LI-6400 portable photosynthesis system (Licor, Lincoln, NE, USA) equipped with a 6400-22L chamber and a 6400-18 light source. All twigs were wrapped in a moist towel before the gas exchange measurement. One part of the twig was immediately placed in the chamber and the cut ends were covered by the moistened filter paper. Measurements were made in a standard condition of $25^{\circ} \mathrm{C}$, a $\mathrm{CO}_{2}$ concentration of $450 \mathrm{ppm}$, and $60 \%$ relative humidity. For dark respiration $\left(R_{d}\right)$, the twig in the dark chamber was acclimated for $20 \mathrm{~min}$ prior to the measurements. For the light curve measurement, the PAR series was set as $1500,1200,1000,800,600,400,200,100,80,50$, and $20 \mu \mathrm{mol} \mathrm{m}^{-2} \mathrm{~s}^{-1}$, and the twig in the chamber was acclimated for $20 \mathrm{~min}$ at $200 \mu \mathrm{mol} \mathrm{m}^{-2} \mathrm{~s}^{-1}$ PAR before the twig $\mathrm{CO}_{2}$ release rate at each $P A R\left(R_{l}\right)$ was measured. The twig gross photosynthetic rate at each PAR $(A)$ was calculated as the absolute value between $R_{d}$ and $R_{l}$ :

$$
A=R_{d}-R_{l}
$$




\subsubsection{Effective Photochemical Efficiency Determination}

From each twig, a $1 \mathrm{~mm}$ thick section was taken from the middle segment, and the $\Phi P S I I$ was immediately examined by the MICRO-version of the IMAGING-PAM (WALZ, Effeltrich, Germany). According to Wittmann and Pfanz's suggestion [10], light intensity less than $54 \mu \mathrm{mol} \mathrm{m}^{-2} \mathrm{~s}^{-1}$ did not trigger the photoinhibition in the stem tissues of the pith, xylem, and cortex of woody plants. In order to compare the difference of $\Phi P S I I$ among the twig tissues in Salix matsudana, the PAR intensity of actinic light was conservatively set as $17 \mu \mathrm{mol} \mathrm{m}^{-2} \mathrm{~s}^{-1}$ to avoid tissue photoinhibition. The samples were adapted for $2 \mathrm{~min}$ under $17 \mu \mathrm{mol} \mathrm{m}^{-2} \mathrm{~s}^{-1}$, then steady state fluorescence intensity in the light-adapted state $\left(F_{S}\right)$ and maximum fluorescence intensity in the light-adapted state $\left(F_{M}{ }^{\prime}\right)$ were measured. $\Phi P S I I$ was calculated as the following formula:

$$
\Phi P S I I=\left(F_{M}^{\prime}-F_{S}\right) / F_{M}^{\prime}
$$

During the period, moistened filter paper was put on the top of the cross section at all times to avoid section dehydration. ImagingWin v2.3.2 software (Walz, Effeltrich, Germany) was used to analyze the radial variety of $\Phi P S I I$ from pith to epidermis, and to select the region of pith, xylem, and cortex to obtain the average value.

\subsubsection{Twig Photosynthetic Pigment Content}

A quantity of 100-200 mg fresh weight (FW) stem segment was ground to fine powder with liquid nitrogen, and then put in tubes containing $5 \mathrm{~mL} 80 \%(v / v)$ acetone. The tubes were incubated in darkness at room temperature until all the powder turned a white color. The absorbance of the supernatant was measured at $663 \mathrm{~nm}, 646 \mathrm{~nm}$, and $470 \mathrm{~nm}$ with a spectrophotometer (UV 160, Shimadzu, Japan).

\subsubsection{Soluble Sugar and Starch Analyses}

Soluble sugar (SS) and starch (St) content was performed as previously described in [27]. The stem segments were oven-dried and ground to a fine powder. SS was extracted from the dried powder of $100 \mathrm{mg}$, which was dissolved in $5 \mathrm{~mL}$ of $80 \%$ ethanol $(v / v)$ in a polyethylene tube. The mixture was boiled in a water bath at $95^{\circ} \mathrm{C}$ for $30 \mathrm{~min}$, and then centrifuged at $3500 \times g$ for $10 \mathrm{~min}$. The supernatant was collected, and the pellet was re-extracted twice with the above steps. The total supernatants were reserved in a fixed capacity of $100 \mathrm{~mL}$. Total SS was determined on the supernatants following the anthrone method. Total St was determined on the remaining pellets after the ethanol extractions. A total of $2 \mathrm{~mL}$ distilled water was added, and the mixture was placed in a boiling water bath for $15 \mathrm{~min}$. After cooling, $2 \mathrm{~mL}$ perchloric acid solution of $9.2 \mathrm{~mol} \mathrm{~L}^{-1}$ was added and a waiting time of $15 \mathrm{~min}$ was given for degrading starch into SS, and then the product was centrifuged at $3500 \times g$ for $10 \mathrm{~min}$. The supernatant was collected, and the pellet was re-degraded twice. The SS of the supernatants was determined, and the St was calculated by the soluble sugar multiplied by 0.9 , which was the coefficient of glucose conversion into starch.

$\mathrm{SS}$ and St contents $\left(\mathrm{mg} \mathrm{gDW}^{-1}\right)$ were calculated as the content of the measured pool divided by the DW of the stem segment sample. Nonstructural carbohydrate (NSC) concentrations were calculated as the sum of SS and St.

\subsubsection{Carbon Isotope Analysis}

Bud and stem bark samples were analyzed for their carbon isotope composition using a MAT 253 Isotope Ratio Mass Spectrometer (IRMS) (Thermo Fisher Scientific, Waltham, MA, USA) coupled with a Flash EA1112 HT Elemental Analyzer (Thermo Fisher Scientific, Waltham, MA, USA). The isotope 
composition was calculated from the sample isotopic ratio ${ }^{13} \mathrm{C} /{ }^{12} \mathrm{C}\left(\mathrm{R}_{\mathrm{s}}\right.$, in $\%$ notation) measured by the IRMS according to the following relationship:

$$
\delta^{13} \mathrm{C}=\left(\left(\mathrm{R}_{\mathrm{s}} / \mathrm{RPDB}\right)-1\right) \times 1000
$$

where RPDB is the international standard constant (Pee Dee Belemnite) $=0.0112372$. The long-term precision for $\mathrm{C}$ isotope measurements was $0.1 \%$.

\subsection{Statistical Analysis}

The statistical analysis of the data was processed using the analysis of variance (one-way ANOVA) and differences between the treatments were assessed using Tukey post hoc tests with SPSS 19.0 statistics software (SPSS Inc., Chicago, IL, USA). Differences between treatments were considered significant if $p<0.05$.

\section{Results}

\subsection{Radial Heterogeneity of $\Phi P S I I$ in the Twig Cross Section}

The effective photochemical efficiency of PSII ( $D P S I I)$ was detected in the whole region of the twig cross section under $17 \mu \mathrm{mol} \mathrm{m}{ }^{-2} \mathrm{~s}^{-1}$ (Figure 1a). It increased along the radial direction from the pith to epidermis (Figure 1b). The greatest value was located in the cortex tissue (Figure 1c). Although the xylem and pith were located in the inner part of the twig, the $\Phi P S I I$ was still detected in living cells, but the values were both significantly lower than the cortex $(p<0.05)$ (Figure 1c).

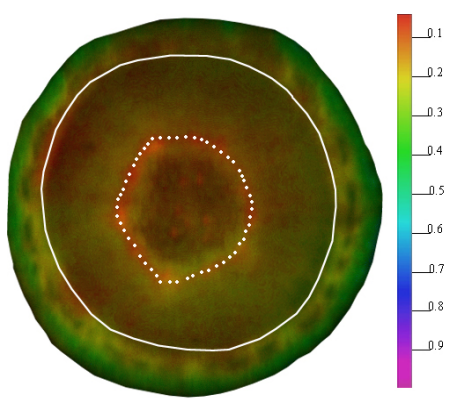

(a)

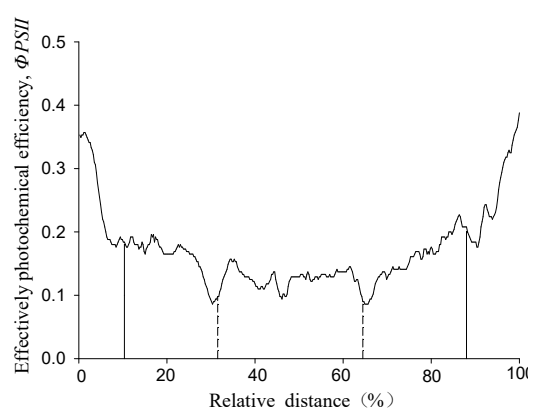

(b)

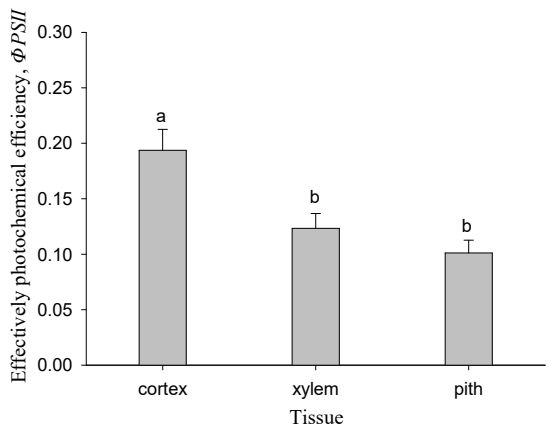

(c)

Figure 1. The spatial heterogeneity of $\Phi P S I I$ in the twig cross section of Salix matsudana. (a) The $\Phi P S I I$ image of the twig cross section. The different colors indicate the different values of $\Phi P S I I$. The solid line indicates the position of the cambium, while the dotted line indicates the border between xylem and pith. (b) ФPSII was measured along the transection of the twig cross section. Transection (from 9 o'clock to 3 o'clock direction) was taken from the SPSII images of (a). The solid line indicates the position of the cambium, while the dotted line indicates the border between the xylem and pith. (c) the difference of $\Phi P S I I$ among the tissues in the twig cross section under $17 \mu \mathrm{mol} \mathrm{m}^{-2} \mathrm{~s}^{-1}$. Data were mean $\pm \mathrm{SE}$ (standard error) with $n=6$ and different lowercase letters indicate a significant $(p<0.05)$ difference.

\subsection{Response of Gross Photosynthesis Rate with Increasing Light Intensity}

Figure 2 shows the response of stem photosynthetic rates to the increasing light intensity. Within the range of $0-400 \mu \mathrm{mol} \mathrm{m}{ }^{-2} \mathrm{~s}^{-1}$, the twig gross photosynthetic rate was significantly increased with the PAR increasing. The gross photosynthesis rate under $100 \mu \mathrm{mol} \mathrm{m}^{-2} \mathrm{~s}^{-1}$ was significantly higher than that under 20 and $40 \mu \mathrm{mol} \mathrm{m}{ }^{-2} \mathrm{~s}^{-1}$. When the light intensity exceeded $400 \mu \mathrm{mol} \mathrm{m}{ }^{-2} \mathrm{~s}^{-1}$, the photosynthetic rates became stable and approximately saturated at $1.27 \mu \mathrm{mol} \mathrm{m}^{-2} \mathrm{~s}^{-1}$. 


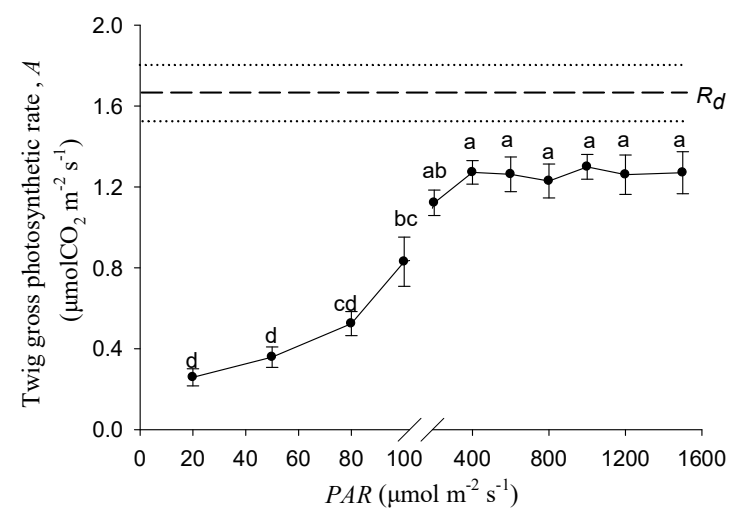

Figure 2. The responses of twig gross photosynthetic rate to different $P A R$. Data were mean $\pm \mathrm{SE}$ with $n=6$. The different lowercase letters indicate a significant $(p<0.05)$ difference among the light intensities. $R_{d}$ represents the dark respiration rate, and dashed and dotted lines represent the mean and mean $\pm \mathrm{SE}$ of $R_{d}$.

\subsection{The Responses of Stem Photosynthetic Pigments and New Organ Development to Different} Light Intensities

Table 1 shows the effects of light intensity on photosynthetic pigment content and new organ development. The stem photosynthetic pigment contents were tested after a 14-day treatment period. The results are summarized in Table 1, which showed that chlorophyll a, chlorophyll b, and the carotenoid contents were significantly affected by light intensity, and the contents under $20 \mu \mathrm{mol} \mathrm{m}{ }^{-2} \mathrm{~s}^{-1}$ were significantly higher than those treated in darkness. It was noted that there was no significant difference between the 20 and $100 \mu \mathrm{mol} \mathrm{m}^{-2} \mathrm{~s}^{-1}$ treatments. Light intensity had a significant positive effect on bud development. Under the treatment of $100 \mu \mathrm{mol} \mathrm{m}^{-2} \mathrm{~s}^{-1}$, bud numbers, bud DW, and the ratio of bud DW to total DW were significantly higher than those treated under light intensities of 0 and $20 \mu \mathrm{mol} \mathrm{m}{ }^{-2} \mathrm{~s}^{-1}$. For example, these numbers were 1.66, 3.65, and 3.92 times higher than those following the darkness treatment, respectively (Table 1). The same trends were also observed for the root, though there were no significant differences between treatments for the root length, root DW, and ratio of root DW to total DW under the treatment of $100 \mu \mathrm{mol} \mathrm{m} \mathrm{m}^{-2} \mathrm{~s}^{-1}$, which were both significantly higher than in darkness (Table 1).

Table 1. Stem photosynthetic pigments contents and organ growth of the cutting seedlings exposed to different light intensities. The different lowercase letters in the same row indicate significant $(p<0.05)$ differences between light intensity treatments.

\begin{tabular}{|c|c|c|c|}
\hline \multirow{2}{*}{ Indicators (mean $\pm \mathrm{SE}$ ) } & \multicolumn{3}{|c|}{ Light Intensity $\left(\mu \mathrm{mol} \mathrm{m}^{-2} \mathrm{~s}^{-1}\right)$} \\
\hline & $\mathbf{0}$ & 20 & 100 \\
\hline Chlorophyll a content $\left(\mathrm{mg} \mathrm{gDW}^{-1}\right)$ & $0.30 \pm 0.01^{b}$ & $0.40 \pm 0.01^{\mathrm{a}}$ & $0.35 \pm 0.02^{a b}$ \\
\hline Chlorophyll b content $\left(\mathrm{mg} \mathrm{gDW}^{-1}\right)$ & $0.07 \pm 0.00^{\mathrm{a}}$ & $0.08 \pm 0.00^{\mathrm{a}}$ & $0.08 \pm 0.00^{\mathrm{a}}$ \\
\hline Total chlorophyll content $\left(\mathrm{mg} \mathrm{gDW}^{-1}\right)$ & $0.37 \pm 0.01^{b}$ & $0.48 \pm 0.01^{\mathrm{a}}$ & $0.43 \pm 0.03^{\mathrm{ab}}$ \\
\hline Carotenoid content $\left(\mathrm{mg} \mathrm{gDW}^{-1}\right)$ & $0.05 \pm 0.00^{b}$ & $0.06 \pm 0.00^{\mathrm{a}}$ & $0.05 \pm 0.00^{\mathrm{ab}}$ \\
\hline Bud number & $5.33 \pm 0.60^{b}$ & $7.17 \pm 0.73^{b}$ & $14.17 \pm 0.17^{\mathrm{a}}$ \\
\hline Bud biomass (mg) & $6.00 \pm 1.76^{b}$ & $9.28 \pm 2.75^{b}$ & $27.92 \pm 2.18^{\mathrm{a}}$ \\
\hline Bud DW: total DW $\left(\mathrm{mg} \mathrm{g}^{-1}\right)$ & $4.39 \pm 1.13^{b}$ & $5.99 \pm 2.37^{\mathrm{b}}$ & $21.60 \pm 2.26^{\mathrm{a}}$ \\
\hline Root length $(\mathrm{cm})$ & $23.90 \pm 3.23^{a}$ & $26.85 \pm 3.65^{\mathrm{a}}$ & $40.00 \pm 5.52^{\mathrm{a}}$ \\
\hline Root DW (mg) & $4.82 \pm 1.21^{\mathrm{b}}$ & $6.38 \pm 0.86^{\mathrm{ab}}$ & $8.97 \pm 0.47^{\mathrm{a}}$ \\
\hline Root DW:total DW (mg g $\left.{ }^{-1}\right)$ & $3.55 \pm 0.62^{b}$ & $3.76 \pm 0.28^{a b}$ & $8.01 \pm 1.61^{\mathrm{a}}$ \\
\hline
\end{tabular}

DW: dry weight; SE: standard error. 


\subsection{Effects of Light Intensity on the Water Content of Stem}

After 14 days of treatment, the proportions of the die back area to the total stem surface were significantly reduced with increasing light intensity. Figure 3 a shows that under the darkness treatment, the proportion was 5.86 times higher than the $100 \mu \mathrm{mol} \mathrm{m}^{-2} \mathrm{~s}^{-1}$ treatment. The stem absolute water contents were positively correlated with light intensity, and the cutting seedlings exposed to $100 \mu \mathrm{mol} \mathrm{m}{ }^{-2} \mathrm{~s}^{-1}$ had the highest stem water content, which was significantly higher than the darkness treatment (Figure 3b).

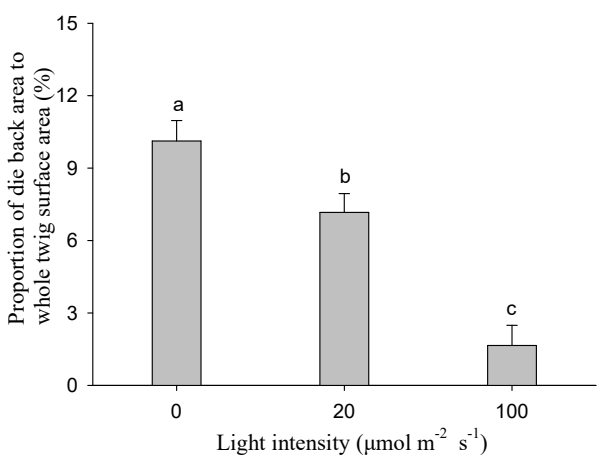

(a)

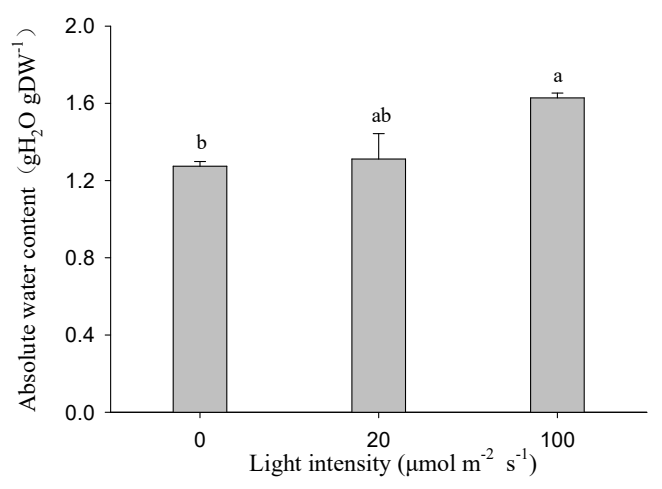

(b)

Figure 3. Die back proportion (a) and absolute water content (b) of the twigs exposed to different light intensities. Data were mean \pm SE with $n=3$. The different lowercase letters above the column indicate the significant $(p<0.05)$ difference between light intensity treatments.

\subsection{Effects of Light Intensity on the SS, St, and Non-Structural Carbohydrate Contents of Stem}

Figure 4 shows the effect of light intensity on the nonstructural carbohydrates content in the stem of the cutting seedlings. The soluble sugar (SS) and starch (St) content were greatly affected by the stem photosynthesis $(p<0.05)$. It was seen that the stem SS contents were significantly lower than in darkness when exposed to 20 and $100 \mu \mathrm{mol} \mathrm{m}{ }^{-2} \mathrm{~s}^{-1}$ treatments. In contrast to SS, the stem starch content increased with the increase of light intensity. For example, St was $144.52 \mathrm{mg} \mathrm{g}^{-1}$ under the $100 \mu \mathrm{mol} \mathrm{m}{ }^{-2} \mathrm{~s}^{-1}$ treatment, which was significantly higher than the $105.07 \mathrm{mg} \mathrm{g}^{-1}$ under the condition of darkness. However, few significant differences were detected between treatments for the stem NSC contents.

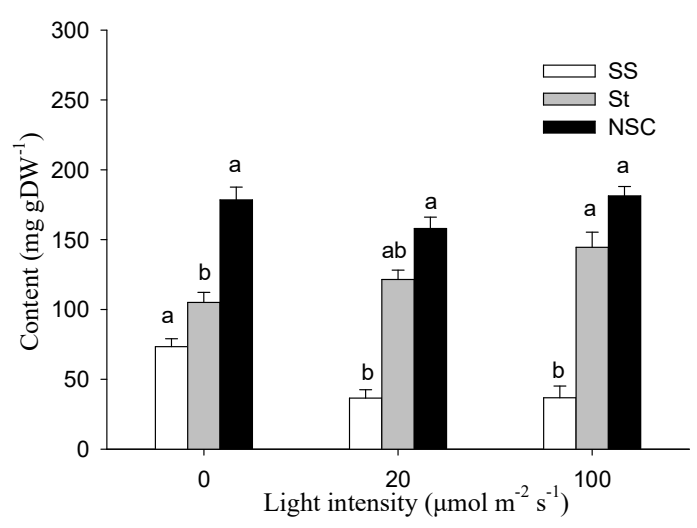

Figure 4. Effects of stem photosynthesis on soluble sugar (SS), starch (St), and NSC (SS + St) content of bud-free stem in cutting seedlings. Data were mean $\pm \mathrm{SE}$ with $n=3$. The different lowercase letters in the same index indicate a significant $(p<0.05)$ difference between light treatments. 


\subsection{Effects of Light Intensity on $\delta^{13} \mathrm{C}$ of Bud and Bark in Cutting Seedlings}

Figure 5 shows that light intensity had a significantly negative influence on $\delta^{13} \mathrm{C}$ values for buds. The $\delta^{13} \mathrm{C}$ of buds exhibited a progressive decrease with increasing light intensity. The most negative value of bud was found in $100 \mu \mathrm{mol} \mathrm{m} \mathrm{m}^{-2} \mathrm{~s}^{-1}$, which was $-27.07 \%$, significantly lower than the $-24.94 \%$ under darkness. There were no significant differences for $\delta^{13} \mathrm{C}$ in stem bark between these treatments. Compared to bark, the bud had significantly higher values of $\delta^{13} \mathrm{C}$ for each light treatment.

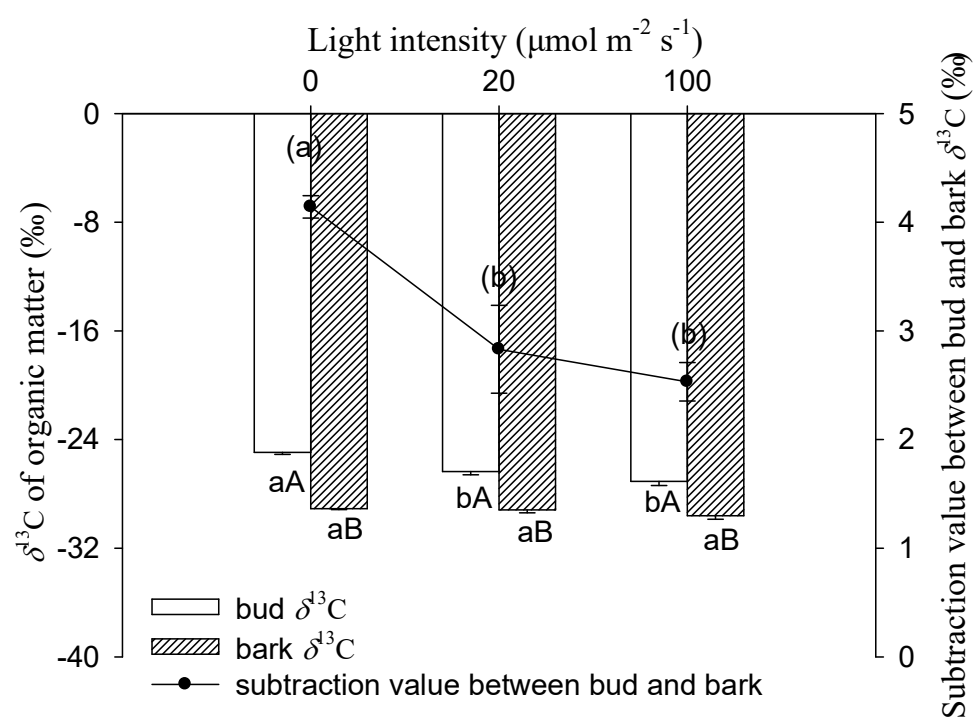

Figure 5. $\delta^{13} \mathrm{C}$ of bud or bark organic matter and the subtraction value between them in cutting seedlings. Data were mean $\pm \mathrm{SE}$ with $n=3$. For the $\delta^{13} \mathrm{C}$ of bud and bark, statistical differences $(p<0.05)$ between (i) treatments for a given organ (different lowercase letters) and (ii) organs for a given treatment (different capital letters) were determined. For the subtraction value between bud and bark $\delta^{13} \mathrm{C}$, the different lowercase letters within the parenthesis indicate a significant difference $(p<0.05)$.

\section{Discussion}

\subsection{Stem Photosynthesis of Twig and Its Response to Different Light Treatment}

In the twig cross section of Salix matsudana, the effective photochemical efficiency ( be detected in all of the tissues, and the value of the cortex was significantly higher than that of the xylem and pith (Figure 1). Identified with other woody plants, twig chloroplasts located in the cortex had the highest photochemical ability [10]. We suggest that the stem inner $\mathrm{CO}_{2}$ re-fixation was mainly contributed by cortical chloroplasts. The tissue-specific ФPSII in twigs of Salix matsudana may be a result of long-term adaptation to the different physicochemical micro-environment among the cortex, xylem, and pith, such as oxygen concentration, light intensity, and $\mathrm{pH}$, etc. There was an evidence of leaf PSII photochemistry ability, the $\Phi P S I I$ value was determined by the altitude in leaves from European beech (Fagus sylvatica L.) trees originating from different provenances [28]. According to the rate of stem photosynthesis, the compensation effect of stem assimilates for the potential respiratory carbon loss was evaluated for different woody plants [16,23]. Our results showed that the twig gross photosynthesis rate of Salix matsudana at the saturated PAR of $400 \mu \mathrm{mol} \mathrm{m}^{-2} \mathrm{~s}^{-1}$ was $1.27 \mu \mathrm{molCO}_{2}$ $\mathrm{m}^{-2} \mathrm{~s}^{-1}$, and could compensate for $76 \%$ of carbon loss by respiration (Figure 2).

The twig samples with different photosynthesis rates were essential for researching the effects of stem photosynthesis on the growth of cutting seedlings. According to the response of the twig gross photosynthetic rate (A) to different PAR (Figure 2), between 20 and $100 \mu \mathrm{mol} \mathrm{m}{ }^{-2} \mathrm{~s}^{-1}$, the value of $A$ was significantly higher under light treatment with a greater intensity (Figure 2). Furthermore, 
the stem photosynthetic rate was determined by photosynthetic pigment content. In this study, there were no significant differences between 20 and $100 \mu \mathrm{mol} \mathrm{m}{ }^{-2} \mathrm{~s}^{-1}$ treatments for the contents of chlorophyll $\mathrm{a}$, chlorophyll $\mathrm{b}$, total chlorophyll, and carotenoid in the stem of the cutting seedlings (Table 1). Hence, the light intensity gradient of 20 and $100 \mu \mathrm{mol} \mathrm{m}^{-2} \mathrm{~s}^{-1}$ in our study could ensure that the stem photosynthesis rate went from low to high.

\subsection{Larger Bud and Root Productions Dependent on More Water and Carbohydrates Supply from Stem Determined by Stem Photosynthesis}

The DW and DW:total DW of bud and root under $100 \mu \mathrm{mol} \mathrm{m}^{-2} \mathrm{~s}^{-1}$ were significantly higher than those following the darkness treatment (Table 1), which confirmed our hypothesis that stem photosynthesis promoted the construction of new organs in cutting seedlings of Salix matsudana.

The rooting and sprouting of cutting seedlings rely on the stem water supply. An interesting outcome of our experiment was that the absolute water content under the $100 \mu \mathrm{mol} \mathrm{m}{ }^{-2} \mathrm{~s}^{-1}$ treatment was higher than the other two treatments, whereas the trend of die back proportion was the opposite (Figure 3). We suggest that stem photosynthesis plays a role in maintaining the stem water content. It is likely that the greater root biomass in the $100 \mu \mathrm{mol} \mathrm{m}{ }^{-2} \mathrm{~s}^{-1}$ treatment was responsible for this result (Table 1). Furthermore, several pieces of literature have reported the relationships between stem photosynthesis and stem hydraulic function [29,30] or xylem vulnerability to cavitation [31]. Photosynthetic, hydraulic, and functional traits of 11 plant species with photosynthetic stems from deserts were studied, and the results showed that photosynthetic and hydraulic traits were coordinated [30]. The hydraulic conductivity of stems in mangroves was lower in the covered than light exposed treatment, revealing that hydraulic function depends on stem photosynthesis [29]. Woody tissue assimilates might play a role in the synthesis of xylem surfactants, which reduces xylem vulnerability to cavitation [31]. In this study, leaf buds were harvested when they were not yet autotrophic, and air seeds, which had probably invaded into vessels, resulted in embolism formation. The higher water content of the $100 \mu \mathrm{mol} \mathrm{m}^{-2} \mathrm{~s}^{-1}$ treatment might be a result of the superior embolism resistance determined by stem photosynthesis.

The carbon dynamics of plants have been modeled according to trajectories of $C$ assimilation, C storage mobilization, and C demands [32,33]. In this study, the stored reserves in the stem were the only carbon sources for organ development in darkness, while there were two carbon sources for sinks under the light treatment, one being the stem stored NSC, and the other being the stem photosynthetic assimilates. Exposed to $100 \mu \mathrm{mol} \mathrm{m} \mathrm{m}^{-2} \mathrm{~s}^{-1}$, there were larger root and bud productions than those treated under light intensities of 0 and $20 \mu \mathrm{mol} \mathrm{m}^{-2} \mathrm{~s}^{-1}$; however, the stem NSC content was not lower. This suggests that the stem photosynthetic assimilates contributed to bud and root biomass.

The darkness treatment increased the $\delta^{13} \mathrm{C}$ of the bud and stem bark, which was consistent with the previous report $[18,19]$. The bud organic matter $\delta^{13} \mathrm{C}$ under 20 and $100 \mu \mathrm{mol} \mathrm{m}{ }^{-2} \mathrm{~s}^{-1}$ light intensities were $-26.35 \%$ and $-27.07 \%$, respectively, which were significantly lower than the case in darkness in the cutting seedlings of Salix matsudana (Figure 5). This suggests that some 'light' $\left({ }^{13} \mathrm{C}\right.$ depleted) assimilates had been imported to the bud and reduced the proportion of 'heavy' $\left({ }^{13} \mathrm{C}\right.$ enriched) carbon in the pool of organic matter. In this study, buds were removed before autotrophy, so stem photosynthesis was the only carbon assimilation pathway which produced ${ }^{13} \mathrm{C}$ depleted assimilates under light treatments [18]. Moreover, being supportive of stem photosynthetic assimilates made a contribution to bud biomass. The same trend was observed in bark $\delta^{13} \mathrm{C}$, though the difference was not significant between the treatments. In comparison with the $100 \mu \mathrm{mol} \mathrm{m}{ }^{-2} \mathrm{~s}^{-1}$ treatment, the stem bark $\delta^{13} C$ increased by $0.4 \%$ when exposed to darkness (Figure 5), which was considered comparable with the increment of $0.6 \%$ in the branch bark of Pinus monticola Douglas ex D. Don after light exclusion [24].

In this study, buds were more enriched in ${ }^{13} \mathrm{C}$ than the stem bark for all treatments (Figure 5). The results were in good accordance with earlier studies, which reported that $\delta^{13} \mathrm{C}$ in buds was less negative than stem bark at the sugar [18] and organic matter [19] levels. First, the biochemical 
composition may be different between bark and bud, and be more depleted in compounds such as lignin, and lipids in bark might result in the more negative $\delta^{13} C$ [20]. Second, maintenance respiration plays a role in the isotopic enrichment of respiratory $\mathrm{CO}_{2}[20,34]$, and there was a positive correlation between the respiratory enrichment and the proportion of maintenance respiration [20]. Mass balance dictates that the enrichment of respiratory $\mathrm{CO}_{2}$ must be opposed by a depleted reserved carbon pool. Compared to the new buds in the cutting seedlings of Salix matsudana, the proportion of maintenance respiration to growth respiration was probably higher in bark. This may result in more ${ }^{13} \mathrm{C}$ depletion in bark organic matter relative to bud. Although bud was more enriched relative to bark, the subtraction values of $\delta^{13} \mathrm{C}$ between bud and bark under the 20 and $100 \mu \mathrm{mol} \mathrm{m} \mathrm{m}^{-2} \mathrm{~s}^{-1}$ treatments were both significantly lower than those in darkness (Figure 5). This suggests that more ${ }^{13} \mathrm{C}$ depletion assimilates originated from the stem photosynthesis imported to bud than to bark under light treatment.

\section{Conclusions}

This study was the first comparative experiment to investigate the effect of stem photosynthesis on the construction of cutting seedlings. The results of stem water and NSC content demonstrated that stem photosynthesis played a significant role in the maintenance of water and starch supply. The results of bud $\delta^{13} \mathrm{C}$ revealed that stem photosynthetic assimilates can contribute to the new organ biomass. Both of the above two aspects resulted in the higher DW of bud and root production under the $100 \mu \mathrm{mol} \mathrm{m}^{-2} \mathrm{~s}^{-1}$ treatment when compared to those treated in darkness, evidence that stem photosynthesis promoted the development of new organs in cutting seedlings of Salix matsudana. Our findings pointed out that for the stem cutting propagation of woody plants, when using stems with abundant chlorenchyma as cuttings, the light condition should be taken into account as an important environmental factor, and appropriate light intensity may promote the morphology construction of cutting seedlings.

Acknowledgments: This work was supported by the Fundamental Research Funds for the Central Non-Profit Research Institution of Chinese Academy of Foresttry (CAFYBB2014QA003 and RIF 2013-04); and the National Natural Science Foundation of China (31600489). The authors thank Jinyao Zhang, Hao Shen, and Pengpeng Lang of the Chinese Academy of Forestry for their assistance in the experiment arrangement and sample processing, Yuan Cao of the State Key Laboratory of Tree Genetics and Breeding, Chinese Academy of Forestry for the physiological analyses, and Zhigang Wu of the School of Civil Engineering, Guangzhou University for his help with the manuscript writing.

Author Contributions: J.L. and Z.S. designed the experiments. J.L., L.G., and Y.Y. performed the experiments. J.L. wrote the initial draft of the article. G.J. and Z.S. revised and edited the article. All authors read and approved the final manuscript.

Conflicts of Interest: The authors declare no conflict of interest.

\section{References}

1. Lendzian, K.J. Survival strategies of plants during secondary growth: Barrier properties of phellems and lenticels towards water, oxygen, and carbon dioxide. J. Exp. Bot. 2006, 57, 2535-2546. [CrossRef] [PubMed]

2. Steppe, K.; Saveyn, A.; McGuire, M.A.; Lemeur, R.; Teskey, R.O. Resistance to radial $\mathrm{CO}_{2}$ diffusion contributes to between-tree variation in CO2 efflux of Populus deltoides stems. Funct. Plant Biol. 2007, 34, 785-792. [CrossRef]

3. Pfanz, H.; Aschan, G. The existence of bark photosynthesis in woody plants and its significance for the overall carbon gain. An eco-physiological approach. Prog. Bot. 2001, 62, 477-510.

4. Manetas, Y. Probing corticular photosynthesis through the in vivo chlorophyll fluorescence measurements: Evidence that high internal $\mathrm{CO}_{2}$ levels suppress electron flow and increase the risk of photoinhibition. Physiol. Plant. 2004, 120, 509-517. [CrossRef] [PubMed]

5. Pfanz, H. Bark photosynthesis. Trees 2008, 22, 137-138. [CrossRef]

6. Pilarski, J.; Tokarz, K.; Kocurek, M. Comparison of photosynthetic pigment contents in stems and leaves of fruit trees: Cherry, sweet cherry, common plum, and walnut tree. Folia Hortic. 2007, 19, 53-65. 
7. Rentzou, A.; Psaras, G.K. Green plastids, maximal PSH photochemical efficiency and starch content of inner stem tissues of three Mediterranean woody species during the year. Flora 2008, 203, 350-357. [CrossRef]

8. Berveiller, D.; Kierzkowski, D.; Damesin, C. Interspecific variability of stem photosynthesis among tree species. Tree Physiol. 2007, 27, 53-61. [CrossRef] [PubMed]

9. Yiotis, C.; Petropoulou, Y.; Manetas, Y. Evidence for light-independent and steeply decreasing PSII efficiency along twig depth in four tree species. Photosynthetica 2009, 47, 223-231. [CrossRef]

10. Wittmann, C.; Pfanz, H. The optical, absorptive and chlorophyll fluorescence properties of young stems of five woody species. Environ. Exp. Bot. 2016, 121, 83-93. [CrossRef]

11. Pfanz, H.; Aschan, G.; Langenfeld-Heyser, R.; Wittmann, C.; Loose, M. Ecology and ecophysiology of tree stems: Corticular and wood photosynthesis. Naturwissenschaften 2002, 89, 147-162. [PubMed]

12. Wittmann, C.; Pfanz, H. Temperature dependency of bark photosynthesis in beech (Fagus sylvatica L.) and birch (Betula pendula Roth.) trees. J. Exp. Bot. 2007, 58, 4293-4306. [CrossRef] [PubMed]

13. Tarvainen, L.; Wallin, G.; Lim, H.; Linder, S.; Oren, R.; Ottosson, L.M.; Rantfors, M.; Tor-Nqern, P.; Marshall, J. Photosynthetic refixation varies along the stem and reduces $\mathrm{CO}_{2}$ efflux in mature boreal Pinus sylvestris trees. Tree Physiol. 2018, 38, 558-569. [CrossRef] [PubMed]

14. Tokarz, K.; Pilarski, J. Optical properties and the content of photosynthetic pigments in the stems and leaves of the apple-tree. Acta Physiol. Plant. 2005, 27, 183-191. [CrossRef]

15. Wittmann, C.; Aschan, G.; Pfanz, H. Leaf and twig photosynthesis of young beech (Fagus sylvatica) and aspen (Populus tremula) trees grown under different light regime. Basic Appl. Ecol. 2001, 2, 145-154. [CrossRef]

16. Damesin, C. Respiration and photosynthesis characteristics of current-year stems of Fagus sylvatica: From the seasonal pattern to an estimation over the year. New Phytol. 2003, 158, 465-475. [CrossRef]

17. Wittmann, C.; Pfanz, H. Bark and woody tissue photosynthesis: A means to avoid hypoxia or anoxia in developing stem tissues. Funct. Plant Biol. 2014, 41, 940-953. [CrossRef]

18. Saveyn, A.; Steppe, K.; Ubierna, N.; Dawson, T.E. Woody tissue photosynthesis and its contribution to trunk growth and bud development in young plants. Plant Cell Environ. 2010, 33, 1949-1958. [CrossRef] [PubMed]

19. Simbo, D.J.; Bilcke, N.V.; Samson, R. Contribution of corticular photosynthesis to bud development in African baobab (Adansonia digitata L.) and Castor bean (Ricinus communis L.) seedlings. Environ. Exp. Bot. 2013, 9, 1-5. [CrossRef]

20. Bowling, D.R.; Pataki, D.E.; Randerson, J.T. Carbon isotopes in terrestrial ecosystem pools and $\mathrm{CO}_{2}$ fluxes. New Phytol. 2008, 178, 24-40. [CrossRef] [PubMed]

21. Brugnoli, E.; Farquhar, G.D. Photosynthetic fractionation of carbon isotopes. In Photosynthesis, Physiology and Metabolism; Leegood, R.C., Sharkey, T.D., von Caemmerer, S., Eds.; Kluwer Academic Publishers: Dordrecht, The Netherlands, 2000; pp. 399-434.

22. Aschan, G.; Pfanz, H. Non-foliar photosynthesis-A strategy of additional carbon acquisition. Flora 2003, 198, 81-97. [CrossRef]

23. Cernusak, L.A.; Marshall, J.D. Photosynthetic refixation in branches of Western white pine. Funct. Ecol. 2000, 14, 300-311.

24. Cernusak, L.A.; Marshall, J.D.; Comstock, J.P.; Balster, N.J. Carbon isotope discrimination in photosynthetic bark. Oecologia 2001, 128, 24-35. [CrossRef] [PubMed]

25. Demo, M.; Bako, A.; Huska, D.; Hauptvogl, M. Biomass production potential of different willow varieties (Salix spp.) grown in soilclimatic conditions of south-western Slovakia. Wood Res. 2013, 58, 651-662.

26. Bernardini, A.; Salvatori, E.; Di Re, S.; Fusaro, L.; Nervo, G.; Manes, F. Natural and commercial Salix clones differ in their ecophysiological response to Zn stress. Photosynthetica 2016, 54, 56-64. [CrossRef]

27. Mitchell1, P.J.; O'Grady, A.P.; Tissue, D.T.; White, D.A.; Ottenschlaeger, M.L.; Pinkard, E.A. Drought response strategies define the relative contributions of hydraulic dysfunction and carbohydrate depletion during tree mortality. New Phytol. 2013, 197, 862-872. [CrossRef] [PubMed]

28. Pšidová, E.; Živčák, M.; Stojnić, S.; Orlović, S.; Gömöry, D.; Kučerová, J.; Ditmarova, L.; Strelcova, K.; Brestic, M.; Kalaji, H.M. Altitude of origin influences the responses of PSII photochemistry to heat waves in European beech (Fagus sylvatica). Environ. Exp. Bot. 2017. [CrossRef]

29. Schmitz, N.; Egerton, J.J.G.; Lovelock, C.E.; Ball, M.C. Light-dependent maintenance of hydraulic function in mangrove branches: Do xylary chloroplasts play a role in embolism repair? New Phytol. 2012, 195, 40-46. [CrossRef] [PubMed] 
30. ÁvilaLovera, E.; Zerpa, A.J.; Santiago, L.S. Stem photosynthesis and hydraulics are coordinated in desert plant species. New Phytol. 2017, 216, 1119-1129. [CrossRef] [PubMed]

31. Niels, J.F.; Baerdemaeker, D.; Salomon, R.L.; Roo, L.D.; Steppe, K. Sugars from woody tissue photosynthesis reduce xylem vulnerability to cavitation. New Phytol. 2017, 261, 720-727. [CrossRef]

32. Hoch, G. Carbon reserves as indicators for carbon limitation in trees. In Progress in Botany; Lüttge, U., Beyschlag, W., Eds.; Springer International Publishing: Cham, Switzerland, 2015; Volume 76, pp. 321-346.

33. Piper, F.I.; Fajardo, A. Carbon dynamics of Acer pseudoplatanus seedlings under drought and complete darkness. Tree Physiol. 2016, 36, 1400-1408. [PubMed]

34. Ocheltree, T.W.; Marshall, J.D. Apparent respiratory discrimination is correlated with growth rate in the shoot apex of sunflower (Helianthus annuus). J. Exp. Bot. 2004, 55, 2599-2605. [CrossRef] [PubMed]

(C) 2018 by the authors. Licensee MDPI, Basel, Switzerland. This article is an open access article distributed under the terms and conditions of the Creative Commons Attribution (CC BY) license (http:/ / creativecommons.org/licenses/by/4.0/). 